\title{
Coexpression of PPE 34.9 Antigen of Mycobacterium avium subsp. Paratuberculosis with Murine Interferon Gamma in HeLa Cell Line and Study of Their Immunogenicity in Murine Model
}

\author{
Rajib Deb and P. P. Goswami \\ Division of Animal Biotechnology, Gene Expression Laboratory, Indian Veterinary Research Institute, Izatnagar, UP 243122, India \\ Correspondence should be addressed to Rajib Deb, drrajibdeb@gmail.com
}

Received 28 May 2010; Revised 15 October 2010; Accepted 2 December 2010

Academic Editor: Udo Conrad

Copyright (C) 2011 R. Deb and P. P. Goswami. This is an open access article distributed under the Creative Commons Attribution License, which permits unrestricted use, distribution, and reproduction in any medium, provided the original work is properly cited.

\begin{abstract}
Mycobacterium avium subsp. paratuberculosis (Map) is the causative agent of johne's disease whose immunopathology mainly depends on cell mediated immuneresponse. Genome sequencing revealed various PPE (Proline-Proline-Glutamic acid) protein family of Map which are immunologically importance candidate genes In present study we have developed a bicistrionic construct pIR PPE/IFN containing a $34.9 \mathrm{kDa}$ PPE protein (PPE 34.9) of Map along with a cytokine gene encoding murine gamma Interferon gene $(\operatorname{IFN} \gamma)$ and a monocistrionic construct pIR PPE using a mammalian vector system pIRES 6.1. The construct were transfected in HeLa cell line and expression were studied by Western blot as well as Immunefluroscent assay using recombinant sera. Further we have compared the immunereactivity of these two constructs in murine model by means of DTH study, LTT, NO assay and ELISA. DTH response was higher in pIR PPE/IFN than pIR PPE group of mice, similar finding also observed in case of LTT and NO production assay. ELISA titer of the PIR PPE/IFN was less than that with PPE only. These preliminary finding can revealed a CMI response of this PPE protein of Map and IFN $\gamma$ having synergistic effect on this PPE protein to elicit a T cell based immunity in mice.
\end{abstract}

\section{Introduction}

Mycobacterium avium subsp. paratuberculosisis (MAP) is an intracellular pathogen, the causative organism of Johne's disease (paratuberculosis), a debilitating chronic enteritis in ruminants and has been implicated in Crohn's disease in humans characterised by hepatic granulomas in HIVnegative, nonimmunosuppressed patients [1]. This pathogen can multiply inside mononuclear phagocytes due to presence of various virulence determinants on their surface [2], and it is evident that cell-mediated immune response controls the resulting pathology.

The name PPE is derived from the motifs Pro-Pro-Glu, found in conserved domains near the $\mathrm{N}$ termini of these proteins having 180 amino acid sequences [3]. PPE proteins are thought to be expressed on the cell surface $[4,5]$ and have been found to be immunodominant antigens [6]. Some of the PPE proteins of Mycobacterium species have been reported to be potent $\mathrm{T}$ cell and or $\mathrm{B}$ cell antigens [7-14].

Although studies on various secretory proteins of mycobacterial species have shown that they are potential immunogens and can be used as subunit vaccine, using efficient immune adjuvants can enhance the performance of the DNA vaccine. Various cytokines especially IFN $\gamma$, IL-2, IL-6, IL-12, and IL-1 play a key role in immunity against mycobacterial infections [15] and have been shown to increase the protectivity while used for coimmunization with DNA vaccines. The essential task of IFN $\gamma$ in the resistence of mice to mycobacterial infections has been make clear by reports that knockout of IFN $\gamma$ gene from the mice cannot control or inhibit different mycobacterial infections [16]. Recently, a recombinant PPE protein, Map41, which has been 
reported as one of the IFN- $\gamma$-inducing antigens of MAP, also strongly induced IL-10 from macrophages obtained from infected calves [14].

Bicistronic vectors have been used to design DNA vaccine against HIV infection, which contained gp120 and GM-CSF gene [17], bicistronic DNA vaccine containing apical membrane antigen 1 and merozoite surface protein 4/5 can prime humoral and cellular immune responses and partially protect mice against virulent plasmodium chabaudi adami DS malaria [18], and a bicistronic woodchuck hepatitis virus core and gamma interferon DNA vaccine can protect from hepatitis [19]. Recently from our laboratory, Kadam et al. [20], have reported that coexpression of IFN $\gamma$ with a $16.8 \mathrm{kDa}$ gene of MAP can enhance immunogenicity of DNA vaccine using the same protein. In the present study, we have used a similar approach to clone a $34.9 \mathrm{kDa}$ PPE (PPE34.9) antigen of MAP in the A frame of the bicistronic vector pIRES 6.1 having IFN $\gamma$ gene in the frame B used by Kadam et al. [20]. Further, we have studied the coexpression of these two antigens in HeLa cell line. We have also preliminary attempted to elucidate the immunogenic effect of PPE 34.9 antigen of MAP on murine model and the role of IFN $\gamma$ 's adjuvant properties.

\section{Materials and Methods}

2.1. Mycobacterial Strains. Solid and liquid cultures of MAP 316F were obtained from Central Diengenees Kunding Tieh Institute, Lelystad, the Netherlands and maintained at Biological Products Division of IVRI, Izatnagar, and later maintained at Gene Expression Laboratory, Division of Animal Biotechnology, IVRI, Izatnagar.

2.2. Plasmid Vectors and Host Strain Used. pTZ57R/T Cloning vector and host strain DH5 $\alpha$ of $E$. coli were supplied by MBI Fermentas, Germany. Bicistronic vector pIRES 6.1 was supplied from Clontech, USA.

2.3. Laboratory Animals. Swiss albino mice and New Zealand white rabbits were obtained from Laboratory Animal Resource Section, IVRI, Izatnagar. Standard prescribed guidelines for care and use of laboratory animals were followed during the experimentation with these animals.

2.4. Culture and Growth of MAP. MAP organisms were grown on Middlebrook $7 \mathrm{H} 10$ agar enriched with $0.1 \%$ glycerol v/v and 10\% OADC with additional supplementation of Mycobactin J (2mg/L) and were maintained at $37^{\circ} \mathrm{C}$.

2.5. Isolation of Genomic DNA Form MAP. The genomic DNA from MAP was isolated by following the published method [21].

2.6. Oligonucleotide Primers. A set of primers were designed for the specific amplification of the $1080 \mathrm{bp}$ PPE34.9 gene of MAP based on the sequence information of MAP str.k10, complete genome Gene Bank Accession no. AE016958.
Similarly, one set of primers was designed for the amplification of murine interferon gamma gene based on sequence information (Gene bank Accession no. NM_008337). The primers were synthesized by Integrated DNA Technologies, USA. The nucleotide sequences of these primers were as follows (Table 1).

\subsection{Polymerase Chain Reaction and Amplification of PPE34.9 Gene Fragment. Specific amplification of the PPE gene from the genomic DNA of $M$. a. paratuberculosis was carried out using the above-mentioned primers pIRES MAP PPE $F$ and pIRES MAP PPE R. The PCR was carried out in $25 \mu \mathrm{L}$ reaction volume using $1 \mu \mathrm{L}$ of genomic DNA (10 ng) as template, $2.5 \mu \mathrm{L}$ of PCR buffer, $1 \mu \mathrm{L}$ of $\mathrm{MgCl}_{2}(1.5 \mathrm{mM}), 1 \mu \mathrm{L}$ $(25 \mu \mathrm{M})$ of each primers, $1 \mu \mathrm{L}$ of dNTP mix $(200 \mu \mathrm{M}$ of each $\mathrm{dNTP}$ ), and $1 \mathrm{U}$ of Taq DNA polymerase. The volume was made up to $25 \mu \mathrm{L}$ by adding DNase-free water. The thermal cycling steps were carried out in PTC-200 thermocycler MJ Research Inc., USA with initial denaturation at $94^{\circ} \mathrm{C}$ for 5 min followed by 30 cycles with denaturation at $94^{\circ} \mathrm{C}$ for $1 \mathrm{~min}$, annealing at $55.0^{\circ} \mathrm{C}$ for $1 \mathrm{~min}$, extension at $72^{\circ} \mathrm{C}$ for 30 seconds, and final extension at $72^{\circ} \mathrm{C}$ for $10 \mathrm{~min}$. Size of the amplified product was confirmed by using DNA molecular weight marker in a 1\% agarose gel and quantified by spectrophotometric analysis.}

2.8. Cloning of PPE34.9 Gene of MAP in pTZ57R/T Cloning Vector. $2 \mu \mathrm{L}(100 \mathrm{ng})$ of eluted PCR product, $1 \mu \mathrm{L}$ of pTZ57R/T ( $55 \mathrm{ng}), 2 \mu \mathrm{L}$ of $5 \mathrm{X}$ ligation buffer, $1 \mu \mathrm{L}$ of T4 DNA ligase ( 5 units) were mixed in a sterile microcentrifuge tube and the volume was made up to $10 \mu \mathrm{L}$ with nuclease free water. The ligation mixture was kept at $22^{\circ} \mathrm{C}$ overnight and stored at $-20^{\circ} \mathrm{C}$. Competent E. coli DH $5 \alpha$ cells were prepared and transformed with $10 \mu \mathrm{L}$ of ligation mixture as stated above. The transformed cells were spread on LB agar plate containing ampicillin $(100 \mu \mathrm{g} / \mathrm{mL}), \mathrm{X}-\mathrm{GAL}(25 \mu \mathrm{g} / \mathrm{mL})$ and IPTG $(25 \mu \mathrm{g} / \mathrm{mL})$. Appropriate positive and negative controls were processed simultaneously. Plates were incubated at $37^{\circ} \mathrm{C}$ overnight and later stored at $4^{\circ} \mathrm{C}$. Ten white colonies were picked up and grown in LB broth containing ampicillin and incubated at $37^{\circ} \mathrm{C}$ overnight in a shaker incubator at $180 \mathrm{rpm}$. Plasmid DNA was extracted by miniprep plasmid isolation method [22]. Identification of positive colonies was done by Colony PCR and subsequently confirmed by RE analysis and designated as pTZ PPE.

\subsection{Cloning of PPE Gene of MAP in a Mammalian Bicistronic Expression Vector pIRES and Plasmid Construct pIR IFN. The insert from the positive clone pTZ PPE (containing the appropriate restriction sites NheI and EcoRI specific for frame A of pIRES vector) was released by digesting with the enzymes Nhe I and EcoRI. The digested product was then ligated in the frame A after digestion of the vector with Nhe I and EcoRI to prepare monocistronic construct pIR PPE. The ligation mixture was transformed in E. coli competent DH5 $\alpha$ cells. Further, to prepare bicistronic construct pIR PPE/IFN, pIR IFN [20] was used and same strategy was adapted to insert the PPE 34.9 in the frame A.}


TABLE 1: List of specific primers used for the present study.

\begin{tabular}{ll}
\hline Primers & Oligonucleotide sequences \\
\hline pIRES MPPPE & 5' \\
F(Sense) & GCCGCTAGCATGTGGGTCCAGGCCGCCAC \\
pIRES MPPPE & 5' GCCGAATTCTTACTCGGTTCCAGCGTTGC \\
R(Anti sense) & $3^{\prime}$-29 mers \\
IFN & $5^{\prime}$ GCCTCTAGAATGAACGCTACACACTGC \\
F(Sense) & $3^{\prime}$-27 mers \\
IFN & $5^{\prime}$ CCGCGGCCGCTCAGCAGCGACTCCTTTT \\
F(Anti sense) & $3^{\prime}$-28 mers \\
\hline
\end{tabular}

2.10. Preparation of Transfection Grade Plasmid. Large scale purification of the plasmid constructs pIR PPE and pIR PPE/IFN was done using endotoxin-free QIAGEN mega kit according to the manufacturer's instructions (Qiagen, Inc., Valencia, California).

\subsection{Transfection of Plasmid Constructs in HeLa Cell line.} The purified recombinant plasmids pIR PPE and pIR PPE/IFN were transfected to $60-70 \%$ confluent HeLa cells using SuperFect transfection reagent kit, following manufacturer's instructions (QIAGEN, Germany). Briefly, HeLa cell monolayer was subcultured and the cells were seeded in $25 \mathrm{~cm}^{2}$ tissue culture flask. When $60-70 \%$ monolayer was achieved, the cells were used for transfection. $5 \mu \mathrm{g}$ of each DNA in $20 \mu \mathrm{L} \mathrm{TE}$ (pH 7.5) was diluted separately in optiMEM. Then $30 \mu \mathrm{L}$ of superfect transfection reagent was added to the DNA solution. Afterwards, growth medium was aspirated from the dish and cells were washed with two mL DMEM (without serum and antibiotic). Then, $0.8 \mathrm{~mL}$ of the same DMEM were added to the reaction tube containing the transfection complexes and mixed properly. The mixtures thus prepared were layered separately over the cells and incubated for $6 \mathrm{hrs}$ at $37^{\circ} \mathrm{C}$ followed by addition of DMEM with $10 \%$ FCS, and incubation was continued in a humidified $\mathrm{CO}_{2}$ incubator. Cells transfected with the respective plasmid constructs were harvested after $72 \mathrm{hrs}$ of incubation by adding about $80 \mu \mathrm{L}$ of $2 \mathrm{X}$ SDS-PAGE loading buffer, and the expressed proteins were resolved on SDSPAGE and western blotting using hyperimmune sera raised in rabbit against recombinant PPE 34.9 protein $(1: 200$ in PBS).

2.12. RT-PCR (Reverse Transcription Polymerase Chain Reaction) for Conformation of Expression of IFN. One $\mathrm{mL}$ of trizol was layered on the transfected monolayer and the cells were lysed. Total RNA was isolated from the cells and amplified by RT-PCR. The amplified product was checked on $1.5 \%$ agarose. One $\mathrm{mL}$ trizol was added on the transfected monolayer and homogenized by passing the lysate 10 times through a sterile $20 \mathrm{G}$ needle fitted to a syringe and transferred to a sterile $1.5 \mathrm{~mL}$ eppendorf. Further, the sample was kept at room temperature for five minutes. $200 \mu \mathrm{L}$ of chloroform was added to the sample and mixed by vortexing. It was allowed to stand at room temperature for 10 minutes. The sample was then centrifuged at $12000 \mathrm{rpm}$ for 20 minutes. The aqueous phase was collected in a separate vial to which $500 \mu \mathrm{L}$ of isopropanol was added, mixed gently, and kept at room temperature. RNA pallet was washed with $500 \mu \mathrm{L} 70 \%$ ethanol and dissolved in nuclease-free water. The yield of total RNA was determined spectrophotometrically using the formula

$$
\mathrm{OD}_{260} \times 33 \times 200 \times 10^{-3}=\mu \mathrm{g} / \mu \mathrm{L}
$$

RT-PCR was carried out using RT PCR kit (MBI Fermentas, Germany). In a sterile microfuge tube, $2 \mu \mathrm{g}$ of total RNA from PIR PPE/IFN were carried out to which $1 \mu \mathrm{L}$ of random hexamer primer was added and incubated at $70^{\circ} \mathrm{C}$ for $5 \mathrm{~min}$. Then, mixture, $1 \mu \mathrm{L}$ RNase inhibitor, $2 \mu \mathrm{L}$ of DNTP, and $4 \mu \mathrm{L}$ of $5 \mathrm{x}$ RT buffer were added and tube was incubated at $37^{\circ} \mathrm{C}$ for $5 \mathrm{~min}$. Thereafter, $1 \mu \mathrm{L}$ of $\mathrm{m} \mathrm{MLV}$ reverse transcriptase was added and the volume was made up to $20 \mu \mathrm{L}$ by adding nuclease free water. The sample was incubated at $42^{\circ} \mathrm{C}$ for $1 \mathrm{hr}$, followed by incubation at $72^{\circ} \mathrm{C}$ for $10 \mathrm{~min}$. The cDNA was stored at $-20^{\circ} \mathrm{C}$, until used. Amplification of IFN $\gamma$ specific fragment from the cDNA preparation was prepared containing $4 \mu \mathrm{L}$ of the cDNA sample, $2.5 \mu \mathrm{L}$ of $10 \mathrm{x}$ PCR buffer, $200 \mu \mathrm{M}$ of each Dntp, and $50 \mathrm{pMol}$ each primers IFNpIR $\mathrm{F}$ and IFNpIR R. IFN $\gamma$ amplification mixture was subjected to 30 cycles of denaturation $\left(94^{\circ} \mathrm{C}, 1 \mathrm{~min}\right)$, annealing $\left(55^{\circ} \mathrm{C}, 45 \mathrm{sec}\right)$, and extension $\left(72^{\circ} \mathrm{C}, 1 \mathrm{~min}\right)$ with a further final cycle for primer extension $\left(72^{\circ} \mathrm{C}, 5 \mathrm{~min}\right)$.

2.13. Indirect Immunofluorescence Assay (IFA). HeLa cells were seeded in 24 well plates and when a $60-70 \%$ confluent monolayer was achieved, two wells each were transfected with PIR PPE, pIR PPE/IFN, and pIRES (mock) plasmid. After incubation for $72 \mathrm{hr}$ the medium was aspirated from all the wells, and the cells were permeabilized by adding $250 \mu \mathrm{L}$ of $80 \%$ acetone for $30 \mathrm{~min}$. Then, acetone was aspirated and the plate was dried at RT for $1 \mathrm{hr}$. Blocking was done using $1 \% \mathrm{BSA}$ for $2 \mathrm{~h}$ at $37^{\circ} \mathrm{C}$. Primary antibody (hyperimmune sera) was added at $1: 50$ dilution and kept for one hr at $37^{\circ} \mathrm{C}$. This was followed by three gentle washes with PBS. FITClabeled antirabbit conjugate was added at $1: 200$ dilution and kept for $1 \mathrm{hr}$ at $37^{\circ} \mathrm{C}$ followed by washing with PBS and mounted in 50\% PBS-glycerol. Cells were examined under fluorescent microscope.

2.14. Immunization of Animals with Plasmid Constructs. Swiss albino mice supplied by Laboratory Animal Section, IVRI, Izatnagar were maintained on ration comprising wheat dalia $62 \%$, maize $30 \%$, wheat bran $7 \%$, salt $1 \%$, and mineral mixture $25 \mathrm{ppm}$ with $5 \mathrm{~mL}$ milk per mouse. The animals were divided into four groups, namely, A, B, C, and D each containing ten mice. They were vaccinated with the purified recombinant plasmid as shown in the Table 2.

Mice (three numbers) from each group were bled on the 21 st and the 42 nd days for serum separation which were stored at $-20^{\circ} \mathrm{C}$ and used in the determination of antibody titres by ELISA.

2.15. Collection of Macrophages and Splenocytes from PlasmidImmunized mice. On the 42nd day after immunization of mice, four mice from each group were selected randomly. 
TABLE 2: Mice Immunization schedules.

\begin{tabular}{lclcc}
\hline $\begin{array}{l}\text { S. } \\
\text { no. }\end{array}$ & $\begin{array}{c}\text { Mice } \\
\text { group }\end{array}$ & $\begin{array}{l}\text { Plasmid construct } \\
\text { used }\end{array}$ & $\begin{array}{c}\text { First dose } \\
\text { (0 day) }\end{array}$ & $\begin{array}{c}\text { Booster dose } \\
\text { (35th day) }\end{array}$ \\
\hline 1 & A & TE buffer control & $100 \mu \mathrm{g}$ & $100 \mu \mathrm{g}$ \\
2 & B & pIRES mock control & $100 \mu \mathrm{g}$ & $100 \mu \mathrm{g}$ \\
3 & C & pIRESPPE & $100 \mu \mathrm{g}$ & $100 \mu \mathrm{g}$ \\
4 & D & pIRESPPE /IFN & $100 \mu \mathrm{g}$ & $100 \mu \mathrm{g}$ \\
\hline
\end{tabular}

About $5 \mathrm{~mL}$ of sterile RPMI 1640 medium were injected into the peritoneal cavity of each mouse, gently massaged, and the mice were left in the cage for $5 \mathrm{~min}$. Then, the mice were sacrificed by $\mathrm{CO}_{2}$ asphyxiation, and the peritoneal fluid was aspirated. The macrophages in the aspirated fluid were collected by centrifugation and resuspension of the obtained pellet in RPMI 1640 medium and subsequently used for nitric oxide (NO) estimation. After aspiration of peritoneal fluid, abdominal cavity was cut open. Spleens were harvested from sacrificed mice and made into a single cell suspension. The cells suspended in RPMI-1640 were layered over Ficoll-Paque PLUS, and mononuclear splenocytes were isolated by density gradient centrifugation at $1350 \times \mathrm{g}$ for 30 min. Splenocytes thus obtained were used for LTT and RNA isolation.

2.16. Measurement of DTH Reaction. Six mice from each group were selected for DTH study. On the 42nd day after first immunization. All the mice were injected intradermally with $10 \mu \mathrm{g}$ of johnin in right hind foot pad and $10 \mu \mathrm{g}$ of purified PPE 34.9 recombinant protein in the left hind foot pad. The results of the local skin reactions (DTH) were observed after $48 \mathrm{~h}$ by measuring the two transverse diameters of erythema using Vernier calipers with a minimum measurable increment of $0.01 \mathrm{~mm}$. Data was statistically analyzed using Students' $t$-test at a significant level of $P<.05$.

2.17. Lymphocyte Transformation Test (LTT). The mononuclear splenocytes $\left(5 \times 10^{5}\right.$ cells per well $)$ from four mice were placed in 96 well plates (Nunc, Denmark) in complete RPMI-1640 (phenol red free) medium containing 10\% heatinactivated foetal calf serum, $2 \mathrm{mM}$ L-glutamine, $100 \mathrm{U}$ of penicillin, and $100 \mathrm{mg}$ streptomycin per ml. Respective $\mathrm{Ni}$ NTA column-purified recombinant PPE 34.9 [23] and ConA (positive control) were added at the final concentration of $40 \mu \mathrm{g} / \mathrm{mL}$ and $10 \mu \mathrm{g} / \mathrm{ml}$, respectively. RPMI was used as the negative control. The total volume per well was $200 \mu \mathrm{L}$. The plates were kept in a humidified $\mathrm{CO}_{2}$ incubator at $37^{\circ} \mathrm{C}$ for $72 \mathrm{~h}$. At the end of the incubation, $20 \mu \mathrm{L}$ of the yellow tetrazolium salt MTT $(5 \mathrm{mg} / \mathrm{mL})$ were added and incubated at $37^{\circ} \mathrm{C}$ for $4 \mathrm{~h}$. In the presence of living cells, MTT is transformed to purple formazan [24]. Subsequently, $100 \mu \mathrm{L}$ of $0.04 \mathrm{~N} \mathrm{HCl}$ in isopropanol were added and allowed to react for $30 \mathrm{~min}$ to stop the colour development reaction and dissolve the formazan crystals. The absorbance (OD) of the samples was measured in an ELISA reader at $570 \mathrm{~nm}$ (and $650 \mathrm{~nm}$ as reference) wavelength. Assays were conducted in triplicates, and the results expressed as Mean \pm SE. Stimulation index (SI) was calculated using the formula

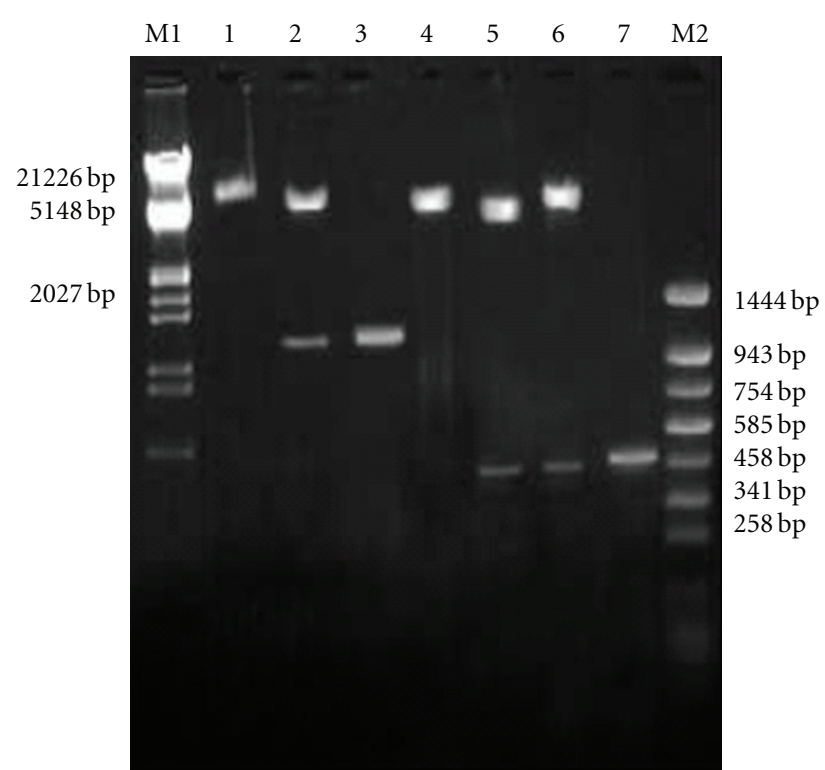

FIGURE 1: Agarose gel electrophoresis (1\%) of the cloned fragment of the gene encoding PPE protein in pIRES IFN PPE mammalian vector. Lane M1: DNA molecular weight marker Lamda DNA/EcoRI/Hind III. Lane 1: pIRES IFN PPE linearised with EcoRI. Lane 2: released insert of $1080 \mathrm{bp}$ after NheI and EcoRI digestion of recombinant pIRES IFN PPE recombinant plasmid DNA. Lane 3: PCR amplified fragment encoding PPE protein of Mycobacterium avium subsp. paratuberculosis. Lane 4: pIR IFN linearised with $\mathrm{Xba}$ I. Lane 5: release IFN fragment (467 bp) by digestion with Xba I and Not I from pIR IFN vector DNA. Lane 6: release IFN fragment (467 bp) by digestion with Xba I and Not I from pIR IFN PPE vector DNA. Lane 7: PCR amplified fragment of IFN (467 bp). Lane M2: DNA molecular weight marker pUC18/Sau3AI-pUC18/TaqI digest.

$\mathrm{SI}=\mathrm{OD}$ of stimulated culture $\div$ OD of unstimulated culture. SI value of $>1.2$ (i.e., $33 \%$ more than the control) was considered for lymphocyte proliferation. Data was analysed for significance between mock pIR and pIR PPE as well as pIR PPE and pIR PPE/IFN constructs by Student's $t$-test, and differences with $P<.05$ were considered within the level of significant.

2.18. NO Production Assay. The RPMI 1640 complete medium was supplemented with $5 \mathrm{mM}$ of L-arginine for this assay. $100 \mu \mathrm{L}$ of the cell suspension containing $2 \times 10^{5}$ peritoneal macrophages from four mice from each group were plated in triplicate in 96 well plates. Respective antigen Ni NTA column-purified recombinant PPE 34.9 [23] and LPS (positive control) in RPMI 1640 medium $(100 \mu \mathrm{L})$ were added at the final concentration of $40 \mu \mathrm{g} / \mathrm{mL}$ and $2 \mu \mathrm{g} / \mathrm{mL}$, respectively. RPMI was used as the negative control. The total volume per well was $200 \mu \mathrm{L}$. The plates were incubated at $37^{\circ} \mathrm{C}$ in a humidified $\mathrm{CO}_{2}(5 \%)$ incubator for $48 \mathrm{~h}$. Supernatants were collected from all the wells and stored at $-20^{\circ} \mathrm{C}$ until $\mathrm{NO}$ estimation. For $\mathrm{NO}$ estimation $\mathrm{NaNO}_{2}$ (sodium nitrite) in different concentrations was used as standard. In a 96-well ELISA plate to $50 \mu \mathrm{l}$ of the cell culture supernatant or standard, $60 \mu \mathrm{L}$ of Griess reagent $(1 \%$ sulfanilamide in $1.2 \mathrm{~N} \mathrm{HCl}$ ) (Sigma) was added, and the plates were incubated at $37^{\circ} \mathrm{C}$ for $30 \mathrm{~min}$, A550 reading was 


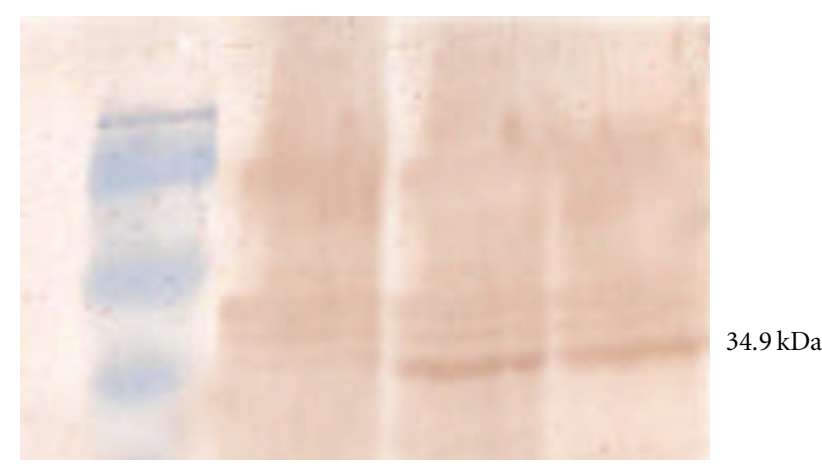

Figure 2: Western blot assay of 72-hour culture of HeLa cell transfected with pIRPPE and pIRPPE/IFN showing expressed $34.9 \mathrm{kDa}$ PPE protein. Lane M: prestained protein molecular weight marker. Lane 1: whole cell lysate of HeLa cell transfected with pIRES (mock control). Lane 2: whole cell lysate of HeLa cell transfected with pIRES PPE. Lane 3: whole cell lysate of HeLa cell transfected with pIRES PPE/IFN.

taken on a microplate ELISA reader. By using the standard curve $\left(\mathrm{NaNO}_{2}\right.$ concentration versus A550) the NO levels in the samples were estimated. Data was analysed by Student's $t$ test, and differences with $P<.05$ were considered significant.

2.19. Characterization of PPE Specific Antibodies in Mice Groups Immunized with Plasmid Constructs by ELISA. The optimum concentration of Ni NTA column-purified recombinant PPE 34.9 [23] antigen and conjugate were determined using block titration as described by Engwal and Pearlman [25]. The wells of ELISA plates (Nunc, Denmark) were coated with $200 \mathrm{ng} /$ well of antigen diluted in carbonate bicarbonate buffer, and the plates were incubated at $4^{\circ} \mathrm{C}$ overnight. The plates were washed thrice with PBS-Tween 20 (PBS-T) and blocked with 5\% skim milk powder in PBS$\mathrm{T}$ for $2 \mathrm{~h}$ at $37^{\circ} \mathrm{C}$. Then, $1: 200$ dilution of serum in $100 \mu \mathrm{L}$ volume of PBS-T were added in duplicate and incubated at $37^{\circ} \mathrm{C}$ for one hour. The plates were washed thrice with PBS-T for $3 \mathrm{~min}$ at each wash. Conjugate antimouse IgG HRPO at dilution of $1: 10,000$ in $100 \mu \mathrm{L}$ volume was added to each well, and the plates were incubated for $1 \mathrm{hr}$ at $37^{\circ} \mathrm{C}$. The plates were then washed three times with PBS-T, and colour was developed with $100 \mu \mathrm{L}$ of $10 \mathrm{mg} / \mathrm{mL}$ OPD with $10 \mu \mathrm{L}$ of $30 \% \mathrm{H}_{2} \mathrm{O}_{2}$ in substrate buffer. After sufficient colour development, the reaction was stopped by the addition of $50 \mu \mathrm{L} 1 \mathrm{~N} \mathrm{H}_{2} \mathrm{SO} 4$, and the plates were read at $490 \mathrm{~nm}$ in an ELISA reader (Tecan, Austria).

\section{Results}

3.1. Construction and Characterization of Plasmids PIR PPE and $p I R$ PPE /IFN. The bicistronic constructs were generated after cloning PPE34.9 gene fragment from Nhe I and Eco RI digested PCR product into frame A of Nhe I and Eco RI digested plasmid vector and Xba I- Not I digested IFN $\gamma$ into frame $\mathrm{B}$ of the same vector. The positive colonies from the construct was identified by obtaining desired size products using colony PCR and subsequently confirmed by the release of identical size inserts on RE analysis (Figure 1).
TABLE 3: DTH responses in mice immunized with plasmid constructs expressed as mean differences $(\mathrm{mm})$ upon recall with 10 microgram of PPE34.9.

\begin{tabular}{lcc}
\hline Groups & PBS & PPE 34.9 \\
\hline Group A (TE buffer as control) & $0.082 \pm 0.001$ & $0.235 \pm 0.018$ \\
Group B pIRES (mock) & $0.082 \pm 0.0007$ & $0.111 \pm 0.011$ \\
Group C pIRES PPE & $0.211 \pm 0.007$ & $2.516 \pm 0.132$ \\
Group D pIRES PPE & $0.215 \pm 0.0104$ & $3.115 \pm 0.005$ \\
\hline
\end{tabular}

The plasmid constructs (monocistronic and bicistronic) were transfected into $60-70 \%$ confluent HeLa cell line, and the expressed PPE34.9 protein was detected from 72-hour posttransfected cell lysate in western blot using polyclonal serum raised in rabbit against recombinant PPE34.9. No such band was observed in cell lysate transfected with mock plasmid (Figure 2). The 72-hour posttransfected HeLa cells with plasmid constructs pIR PPE and PIR PPE/IFN on IFA using FITC-labeled conjugate exhibited fluorescence under fluorescent microscope, indicating the expression of the PPE34.9 protein (Figures 3(a), 3(b), 3(c), and 3(d)). The monoclonal antibodies against murine IFN $\gamma$ could bind with HeLa cell expressed IFN protein to reconfirm IFN $\gamma$ expression from the construct pIRPPE/IFN, RT-PCR was done for the cDNA obtained from total RNA of a 72-hour posttransfected HeLa cell lysate using specific primers of murine IFN $\gamma$. At $55^{\circ} \mathrm{C}$, annealing temperature gave the amplified product of $467 \mathrm{bp}$ (Figure 4).

3.2. Induction of DTH Response. DTH response was measured with Vernier Calipers 72 hrs after injection of PPE34.9 protein in the foot pad of Plasmid-immunized groups of mice. Skin reactions to recombinant PPE34.9 protein was studied. Both the control groups showed no significant reaction to antigen. Mice group immunized with pIR PPE and PIR PPE/IFN evoked visible skin reactions in the form of necrosis and erythema. However, more significant $(3.115 \pm 0.005)$ erythematous lesions were observed in mice immunized with pIR PPE/IFN in comparison to pIR PPEimmunized groups $(2.516 \pm 0.132)$. Whereas, mice immunized with plasmid pIRES (mock) showed no significant swelling when compared to the injection of PBS (Table 3). Statistical analysis with Student's $t$-test showed significant difference $(P<.05)$ between pIR PPE/IFN and pIR PPE alone.

3.3. LTT-Based In Vitro Lymphocyte Proliferation Test. The purified recombinant PPE34.9 protein stimulated a significant proliferation of mononuclear splenocytes from mice groups immunized with constructs pIR PPE and pIR PPE/ IFN. Higher proliferation was obtained with construct pIR PPE/IFN (1.38 \pm 0.079$)$ followed by group pIR PPE $(1.21 \pm$ 0.076) upon stimulation with purified PPE34.9 protein. (Table 4). Statistical analysis with student's $t$-test showed significant difference $(P<.05)$ between pIR (mock) and pIR PPE as well as pIR PPE and pIR PPE/IFN groups.

3.4. NO Production Assay. Peritoneal macrophages collected from various mice groups were stimulated with the respective 


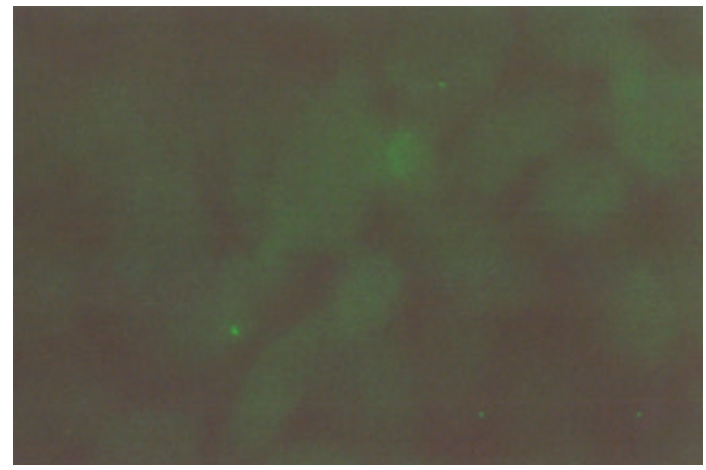

(a)

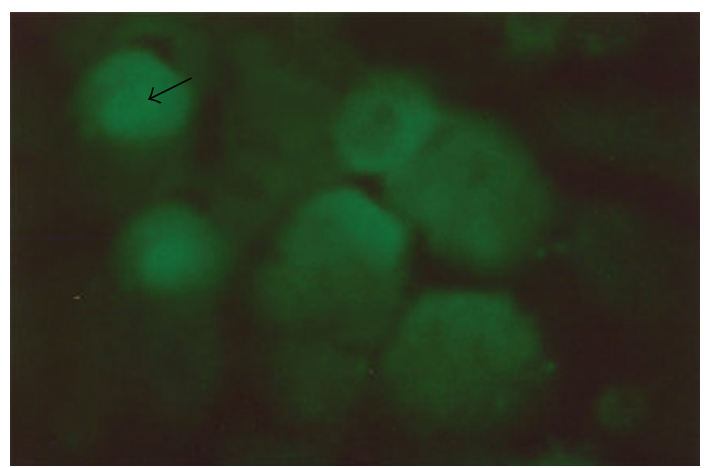

(c)

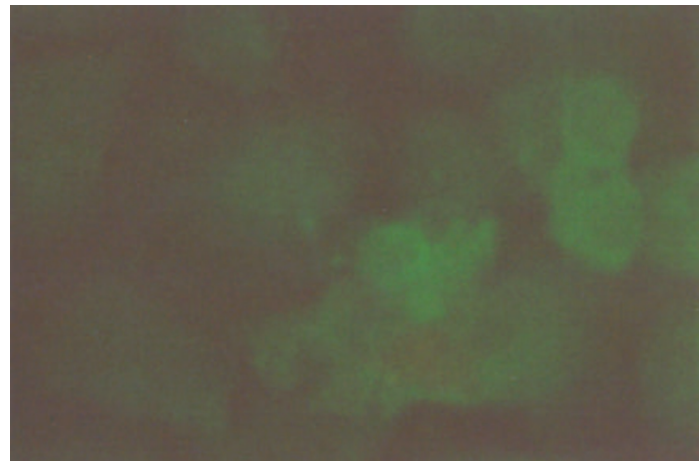

(b)

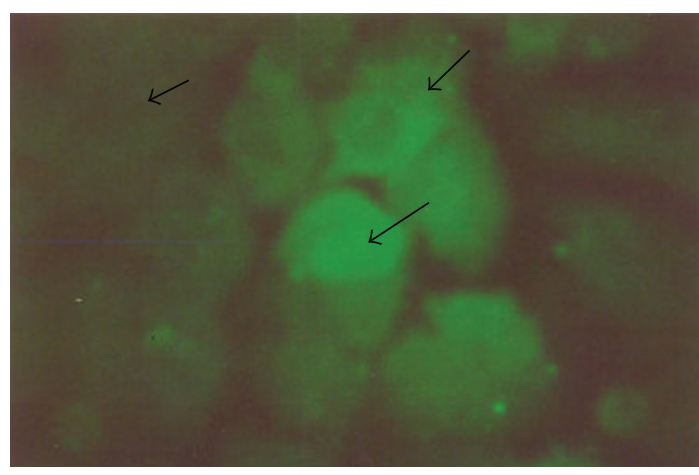

(d)

FIGURE 3: (a) Healthy HeLa cells (untransfected). (b) HeLa cells transfected with pIRES mock control. (c) HeLa cells transfected with pIRES PPE vector construct showing expression of PPE protein using o polyclonal sera raised in rabbit against PPE 34.9 react with FITC-labeled antirabbit conjugate. (d) HeLa cells transfected with pIRES PPE/IFN vector construct showing expression of PPE protein using o polyclonal sera raised in rabbit against PPE 34.9 react with FITC-labeled antirabbit conjugate.

TABLE 4: Lymphocyte transformation test for mice groups immunized with Plasmid constructs (SI = Mean \pm SEM).

\begin{tabular}{lcc}
\hline Groups & ConA & PPE protein \\
\hline A (TE buffer control) & $1.03 \pm 0.05$ & $0.96 \pm 0.042$ \\
B (pIRES mock control) & $1.04 \pm 0116$ & $0.97 \pm 0.031$ \\
C (pIRESPPE) & $1.3 \pm 0.101$ & $1.21 \pm 0.076$ \\
D (pIRESPPE /IFN) & $1.41 \pm 0.17$ & $1.38 \pm 0.079$ \\
\hline
\end{tabular}

antigens to measure the amount of nitric oxide produced by the cells. The quantity of NO produced was estimated by comparing with known standards of sodium nitrite. LPS induced significant production of $\mathrm{NO}$ in all the groups. Among the immunized groups, NO production was found highest in group pIR PPE/IFN (Mean \pm SEM $=38.62 \pm$ $1.02 \mu \mathrm{m} / 2 \times 10^{5}$ cells) followed by group pIR PPE (Mean \pm $\mathrm{SEM}=26.19 \pm 0.53 \mu \mathrm{m} / 2 \times 10^{5}$ cells) upon stimulation with recombinant PPE34.9 protein. (Table 5). Statistical analysis with student's $t$-test showed significant difference $(P<.05)$ between pIR (mock) and pIR PPE as well as pIR PPE and pIR PPE/IFN groups.

3.5. Detection of Immune Response Induced by Various Plasmids Constructs in Mice by ELISA. To evaluate the humoral immune response induced by plasmid constructs in mice
TABLE 5: Nitric oxide production assay of peritoneal macrophages from mice groups immunized with Plasmid constructs ( $\mu \mathrm{m}$ of $\mathrm{NO} / 2 \times 10^{5}$ cells $=$ Mean $\left.\pm \mathrm{SEM}\right)$.

\begin{tabular}{lcc}
\hline Groups & LPS & PPE protein \\
\hline A (TE buffer control) & $29.32 \pm 0.5042$ & $7.85 \pm 0.2933$ \\
B (pIRES mock control) & $30.77 \pm 0.6617$ & $7.29 \pm 0.3199$ \\
C (pIRESPPE) & $33.43 \pm 1.9381$ & $26.19 \pm 0.535$ \\
D (pIRESPPE /IFN) & $40.89 \pm 2.3452$ & $38.62 \pm 1.020$ \\
\hline
\end{tabular}

groups, on the 21st day and the 42nd day postimmunization antibody titres were determined by indirect ELISA. Antibodies were detected in all the plasmid constructs immunized groups of mice $(\mathrm{OD} 490>0.3$ in the serum dilution range of $1: 200)$. Whereas, insignificant titres were observed in control groups (Table 6).

\section{Discussion}

Presently, chemotherapy is unrewarding and economically not feasible to control the diseases. Effective control programmes for the disease are hampered due to lack of specific diagnostic tests to detect infection in the early stages of disease. Further the currently available immunodiagnostic tests have limited sensitivity [26] and specificity [27]. 


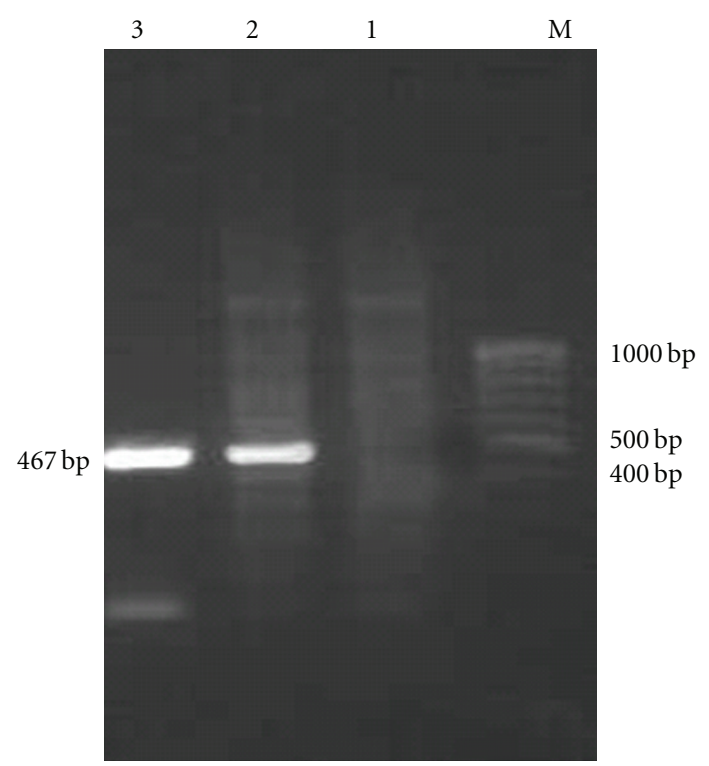

Figure 4: Agarose gel electrophoresis (1.5\%) showing RT-PCR based expression of IFN $\gamma$ ORF in PIR PPE IFN transfected HeLa cells. Lane M: prestained protein molecular weight marker (100 bp ladder). Lane 1: negative control mock plasmid transfected HeLa cells. Lane 2: IFN $\gamma$ encoding gene from pIR PPE IFN transfected HeLa cells with super natant $\gamma$. Lane 3: positive control (IFN $\gamma$ ) encoding gene from ConA induced mice splenocytes.

TABLE 6: ELISA titres of plasmid construct-injected mice groups $\left(\mathrm{OD}_{490}=\right.$ Mean \pm SEM $)$.

\begin{tabular}{lcc}
\hline Groups & 21st day & 42nd day \\
\hline Blank & $0.031 \pm 0.0035$ & $0.044 \pm 0.0034$ \\
A (TE buffer control) & $0.131 \pm 0.0076$ & $0.136 \pm 0.012$ \\
B (pIRES mock control) & $0.142 \pm 0.0371$ & $0.156 \pm 0.012$ \\
C (pIRESPPE) & $0.312 \pm 0.0204$ & $0.322 \pm 0.030$ \\
D (pIRESPPE /IFN) & $0.263 \pm 0.018$ & $0.283 \pm 0.021$ \\
\hline
\end{tabular}

Conventional live attenuated vaccines are not completely protective $[28,29]$. Studies have shown that CMI develops in early stages for clearing infection [30] whereas high serum antibody concentration is often seen in advanced clinical cases [31]. The cell-mediated immunity plays a pivotal role to control the spread of organisms within the host body [32]. DNA vaccines may open new horizons for effective vaccination against paratuberculosis as strong CMI responses including CTL and Th1 type cytokines are induced [20].

Expressions of $\mathrm{T}$ cell antigens in prokaryotic vector have failed to induce CTL and cytokine response. However, expression of $\mathrm{T}$ cell antigen in a mammalian vector for eliciting CD4+ $\mathrm{T}$ cell response and CD8+ cytotoxic $\mathrm{T}$ cell response to generate immunity have been reported in a number of animal models [33-36]. Cytokines also (mainly IFN $\gamma$, TNF $\alpha$, IL10 etc.) play a major role in the protective immune response against mycobacterial diseases [14, 32]. Coexpression of $\mathrm{T}$ cell antigen with costimulatory molecules in a bicistronic eukaryotic system made the DNA vaccine more effective [17-20]. Moreover, expression of two T cell antigens in eukaryotic bicistronic system may also be useful for enhancing protective immunity.

After the completion of the genome sequencing of MAP, the PPE protein family has been widely assumed to represent immunologically important antigens of the mycobacterial species. The present work envisaged keeping in view the role of a PPE antigen and the concept of bicistronic DNA constructs using an immunostimulatory molecule IFN $\gamma$ is likely to potentiate immune response in mice. The use of cytokines as adjuvant is known to enhance immune responses when they were administered during the development of immune response against a particular antigen $[37,38]$. IFN $\gamma$ is the most extensively studied cytokine in mycobacterial infections. It is the defining cytokine of Th1 subset and activates macrophages for microbicidal activity. It induces IL12, which causes Th cells to differentiate into Th1 subset [39].

In the present study, the gene fragment encoding PPE34.9 protein was cloned into the frame $\mathrm{A}$ of the bicistronic vector pIRES6. 1 containing IFN $\gamma$ gene in frame $\mathrm{B}$ and also a monocistronic plasmid construct pIR PPE was made. The constructs were designated as pIR PPE/IFN and pIR PPE, respectively. Bicistronic vector pIRES6.1 contained immediate early CMV promoter for simultaneous expression of the two genes downstream to it as active protein. Expression of the PPE34.9 and IFN $\gamma$. (17 kDa) proteins was confirmed by western blot and immunofluorescence assay in 72-hour posttransfected HeLa cell lysates using polyclonal sera. Size of mouse IFN $\gamma$.gene is $1208 \mathrm{bp}$ in length but coding sequence is $467 \mathrm{bp}$, which was used for IFN $\gamma$. ORF expression. The results were in agreement with the eukaryotic bicistronic expression of $16.8 \mathrm{kDa}$ antigen of MAP and murine IFN $\gamma$. in a bicistronic vector [20], a glycoprotein C of pseudorabies virus [40] and an apical membrane antigen and merozoite surface protein of Plasmodium chabaudi DS malaria [18].

In the present study, we have cloned and coexpressed a $34.9 \mathrm{kDa}$ protein-encoding PPE gene family antigen with IFN $\gamma$ gene in HeLa cell line. Further, we have studied the immune responses of these plasmid constructs in mice. Elucidation of DTH response against recombinant P35 proteins and $16.8 \mathrm{kDa}$ proteins of MAP has been studied by and Basagoudanavar et al. [41] and Kadam et al. [20], respectively. DTH-based immune response is an indicator of T-cell-based immunity. We have already elucidated the DTH response of purified recombinant PPE 34.9 proteinin mice [23]. In the present study we have compare the effect of IFN as pIR PPE/IFN construct on PPE 34.9 as pIR PPE construct, which showed that a significant higher immune response of the first construct on the second one indicate the role of IFN $\gamma$ to elicit a $\mathrm{T}$ cell based immune response.

Cell proliferation as a test has been used to assess DNA vaccines against mycobacterial infections [20, 41]. In the present study, mononuclear splenocytes from mice group immunized with pIR PPE/IFN showed higher cell proliferation than PIR PPE, which may indicate the effect of IFN $\gamma$. IL2 is known as the cytokine for cell proliferation, but IFN $\gamma$ indirectly induces cell proliferation by activating macrophages and increasing antigen presentation which 
induces IL2 receptors on T cell surface, thereby inducing cell proliferation. The results were in consensus as found by other workers who used cytokines as immunoadjuvant in bicistronic DNA vaccine. Chow et al. [42] have reported increased cell proliferation in group that received hepatitis $B$ virus surface protein and IL2 as bicistronic DNA vaccine. Barouch et al. [17] found twofold augmentation of cell proliferation in bicistronic group which coexpressed gp 120 gene of HIV and GMCSF than in monocistronic gp120 immunized group. Kadam et al. [20], also found that bicistronic vector expressing a $16.8 \mathrm{kDa}$ protein of MAP along with IFN $\gamma$ gene induce higher proliferative response than the protein alone.

It is known that RNI $r$ nitrogen intermediates), especially nitric oxide (NO), are most effective in direct killing of mycobacteria [15]. An increased production of NO-induced vaccine candidate genes may be one of the important causes of effective immune response against mycobacterial infection. As in our present study, NO production from cells of pIR PPE/IFN group was comparatively higher than PPE34.9 alone, it may again indicate the role of IFN $\gamma$ in the induction/stimulation of macrophages to release RNI (NO). Recombinant protein PPE 34.9 was purified using singlestep Nickel-NTA (pQE 30 UA containing His tag vector was used) affinity column chromatography [23], chance of LPS/ endotoxin contamination is negligible. The results were in consensus as found by other workers who reported that it plays an important role in release of NO from monocytes $[20,43]$.

ELISA adopted to study the humoral immune response following DNA vaccination in mice for $22 \mathrm{kDa}$ antigen of $M$. bovis [44] and MPT64, Ag85B, and ESAT-6 [45] antigens of $M$. tuberculosis showed significant increase in log titre of circulating antibodies. In the present study, antibody titer of the construct pIR PPE/IFN was less than that with PPE34.9 only. It may be possible that here IFN down regulating the IgG mediate humoral immunity induced by PPE34.9 protein which needs to be further confirmed in large number of animals. This result may be correlated to the groups who find that codelivery of IFN-gamma or IL-4 encoding EG95 protein of Echinococcus granulosus, the causative agent of hydatid appeared to reduce the ability of the DNA vaccine to prime an IgG antibody response demonstrated the efficacy of the codelivery of cytokines to modulate immune responses generated in a DNA prime-protein boost strategy [46].

Overall, the preliminary findings possibly revealed that the PPE34.9 antigen of MAP may be a T-cell-based immunogen. This is in agreement with the studies reported on PE antigen of M. avium by Parra et al. [47], antigen induced both cell-mediated [48] and humoral immune responses [49] which again was in corroboration with the earlier works.

Immune adjuvants plays an important role to enhance the protective efficacy of DNA vaccines [50]. IFN $\gamma$ is a potent activator of macrophages and is the key cytokine in Th1-type immune response in paratuberculosis infection produced by both CD4+ and CD8+ cells [20, 51]. Hence for the development of an effective measure against paratuberculosis, it is necessary to apply those strategies that should enhance the $\mathrm{T}$ cell mediate response. From our preliminary observations, we have also noticed that the monocistronic construct pIR PPE elicited a comparatively milder CMI response than pIR PPE/IFN. This may revealed that the presence of IFN $\gamma$ synergized the T cell response of PPE34.9 protein.

These preliminary observations need further confirmation like in vitro study of the Th1 cytokine mediate response of the PPE34.9 and challenge studies in experimental as well as natural hosts for the development of an effective bicistronic DNA vaccine against paratuberculosis infection.

\section{Abbreviations}

OADC: Oleic acid dextrose catalase

RPMI: Roswell Park Memorial Institute

DMEM: Dulbecco's modified eagle medium

FCS: Fetal calf serum

rpm: Revolutions per minute

DTH: Delayed type hypersensitivity

MTT: 4,5-dimethyl thiazol-2-4 diphenyl tetrazolium bromide

NO: $\quad$ Nitric oxide

ELISA: Enzyme linked immunosorbent assay

RE: $\quad$ Restriction enzyme.

\section{Acknowledgment}

The authors are thankful to the Director of IVRI, Izatnagar for providing the necessary facilities to conduct the present study.

\section{References}

[1] M. Toyoda, H. Yokomori, F. Kaneko et al., "Hepatic granulomas as primary presentation of Mycobacterium avium infection in an HIV-negative, nonimmunosuppressed patient," Clinical Journal of Gastroenterology, vol. 2, no. 6, pp. 431-437, 2009.

[2] Y. J. Li, L. Danelishvili, D. Wagner, M. Petrofsky, and L. E. Bermudez, "Identification of virulence determinants of Mycobacterium avium that impact on the ability to resist host killing mechanisms," Journal of Medical Microbiology, vol. 59, no. 1, pp. 8-16, 2010.

[3] N. C. Gey Van Pittius, S. L. Sampson, H. Lee, Y. Kim, P. D. Van Helden, and R. M. Warren, "Evolution and expansion of the Mycobacterium tuberculosis PE and PPE multigene families and their association with the duplication of the ESAT-6 (esx) gene cluster regions," BMC Evolutionary Biology, vol. 6, article 95, 2006.

[4] M. J. Brennan, G. Delogu, Y. Chen et al., "Evidence that mycobacterial PE_PGRS proteins are cell surface constituents that influence interactions with other cells," Infection and Immunity, vol. 69, no. 12, pp. 7326-7333, 2001.

[5] G. Delogu, C. Pusceddu, A. Bua, G. Fadda, M. J. Brennan, and S. Zanetti, "Rv1818c-encoded PE_PGRS protein of Mycobacterium tuberculosis is surface exposed and influences bacterial cell structure," Molecular Microbiology, vol. 52, no. 3, pp. 725733, 2004.

[6] R. K. Choudhary, S. Mukhopadhyay, P. Chakhaiyar et al., "PPE Antigen Rv2430c of Mycobacterium tuberculosis Induces a Strong B-Cell Response," Infection and Immunity, vol. 71, no. 11, pp. 6338-6343, 2003. 
[7] L. M. Okkels, I. Brock, F. Follmann et al., "PPPE protein (Rv3873) from DNA segment RD1 of Mycobacterium tuberculosis: strong recognition of both specific T-cell epitopes and epitopes conserved within the PPE family," Infection and Immunity, vol. 71, no. 11, pp. 6116-6123, 2003.

[8] J. F. Huntley, J. R. Stabel, M. L. Paustian, T. A. Reinhardt, and J. P. Bannantine, "Expression library immunization confers protection against Mycobacterium avium subsp. paratuberculosis infection," Infection and Immunity, vol. 73, no. 10, pp. 68776884, 2005.

[9] P. R. Marri, J. P. Bannantine, and G. B. Golding, "Comparative genomics of metabolic pathways in Mycobacterium species: gene duplication, gene decay and lateral gene transfer," FEMS Microbiology Reviews, vol. 30, no. 6, pp. 906-925, 2006.

[10] V. Newton, S. L. Mc Kenna, and J. De Buck, "Presence of PPE proteins in Mycobacterium avium subsp. Paratuberculosis isolates and their immunogenecity in cattle," Veterinary Microbiology, vol. 135, pp. 394-400, 2009.

[11] S. Bertholet, G. C. Ireton, M. Kahn et al., "Identification of human $\mathrm{T}$ cell antigens for the development of vaccines against Mycobacterium tuberculosis," Journal of Immunology, vol. 181, no. 11, pp. 7948-7957, 2008.

[12] S. Nair, P. A. Ramaswamy, S. Ghosh et al., "The PPE18 of Mycobacterium tuberculosis interacts with TLR2 and activates IL-10 induction in macrophage," Journal of Immunology, vol. 183, no. 10, pp. 6269-6281, 2009.

[13] R. M. Goldstone, S. D. Goonesekera, B. R. Bloom, and S. L. Sampson, "The transcriptional regulator Rv0485 modulates the expression of a pe and ppe gene pair and is required for Mycobacterium tuberculosis virulence," Infection and Immunity, vol. 77, no. 10, pp. 4654-4667, 2009.

[14] R. Nagata, S. Kawaji, Y. Minakawa, X. Wang, T. Yanaka, and Y. Mori, "A specific induction of interleukin-10 by the Map41 recombinant PPE antigen of Mycobacterium avium subsp. paratuberculosis," Veterinary Immunology and Immunopathology, vol. 135, no. 1-2, pp. 71-78, 2010.

[15] J. Mullerad, A. H. Hovav, R. Nahary, Y. Fishman, and H. Bercovier, "Immunogenicity of a $16.7 \mathrm{kDa}$ Mycobacterium paratuberculosis antigen," Microbial Pathogenesis, vol. 34, no. 2, pp. 81-90, 2003.

[16] J. L. Adams, M. T. Collins, and C. J. Czuprynski, "Polymerase chain reaction analysis of TNF- $\alpha$ and IL- 6 mRNA levels in whole blood from cattle naturally or experimentally infected with Mycobacterium paratuberculosis," Canadian Journal of Veterinary Research, vol. 60, no. 4, pp. 257-262, 1996.

[17] D. H. Barouch, S. Santra, K. Tenner-Racz et al., "Potent CD4 ${ }^{+}$ T cell responses elicited by a bicistronic HIV-1 DNA vaccine expressing gp120 and GM-CSF," Journal of Immunology, vol. 168, no. 2, pp. 562-568, 2002.

[18] A. Rainczuk, T. Scorza, T. W. Spithill, and P. M. Smooker, "A bicistronic DNA vaccine containing apical membrane antigen 1 and merozoite surface protein 4/5 can prime humoral and cellular immune responses and partially protect mice against virulent Plasmodium chabaudi adami DS malaria," Infection and Immunity, vol. 72, no. 10, pp. 5565-5573, 2004.

[19] J. Wang, S. A. Gujar, L. Cova, and T. I. Michalak, "Bicistronic woodchuck hepatitis virus core and gamma interferon DNA vaccine can protect from hepatitis but does not elicit sterilizing antiviral immunity," Journal of Virology, vol. 81, no. 2, pp. 903916, 2007.

[20] M. Kadam, S. Shardul, J. L. Bhagath, V. Tiwari, N. Prasad, and P. P. Goswami, "Coexpression of $16.8 \mathrm{kDa}$ antigen of Mycobacterium avium paratuberculosis and murine gamma interferon in a bicistronic vector and studies on its potential as
DNA vaccine," Veterinary Research Communications, vol. 33, no. 7, pp. 597-610, 2009.

[21] M. T. Dertzbaugh, "Genetically engineered vaccines: an overview," Plasmid, vol. 39, no. 2, pp. 100-113, 1998.

[22] J. Sambrook and D. W. Russel, Molecular Cloning: A Laboratory Manual, Cold Spring Harbor Laboratory Press, Cold spring Harbor, NY, USA, 3 edition, 2001.

[23] R. Deb and P. P. Goswami, "Expression of a Gene Encoding $34.9 \mathrm{kDa}$ PPE Antigen of Mycobacterium avium subsp. paratuberculosis in E. coli," Molecular Biology International, vol. 2010, Article ID 628153, 7 pages, 2010.

[24] M. T. Moss, E. P. Green, M. L. Tizard et al., "Specific detection of Mycobacterium paratuberculosis by DNA hybridization with a fragment of the insertion element IS900," Gut, vol. 32, pp. 395-398, 1991.

[25] E. Engwal and P. Pearlman, "Enzyme linked immunosorbent (ELISA), qualitative assay of immunoglobulin G," Immunochemistry, vol. 8, no. 9, pp. 871-874, 1971.

[26] A. F. Hope, P. F. Kluver, S. L. Jones, and R. J. Condron, "Sensitivity and specificity of two serological tests for the detection of ovine paratuberculosis," Australian Veterinary Journal, vol. 78, no. 12, pp. 850-856, 2000.

[27] I. Olsen, H. G. Wiker, E. Johnson, H. Langeggen, and L. J. Reitan, "Elevated antibody responses in patients with Crohn's disease against a $14-\mathrm{kDa}$ secreted protein purified from Mycobacterium avium subsp. paratuberculosis," Scandinavian Journal of Immunology, vol. 53, no. 2, pp. 198-203, 2001.

[28] N. B. Harris and R. G. Barletta, "Mycobacterium avium subsp. paratuberculosis in Veterinary Medicine," Clinical Microbiology Reviews, vol. 14, no. 3, pp. 489-512, 2001.

[29] J. L. Flynn, "Immunology of tuberculosis and implications in vaccine development," Tuberculosis, vol. 84, no. 1-2, pp. 93101, 2004.

[30] R. W. Sweeney, D. E. Jones, P. Habecker, and P. Scott, "Interferon- $\gamma$ and interleukin 4 gene expression in cows infected with Mycobacterium paratuberculosis," American Journal of Veterinary Research, vol. 59, no. 7, pp. 842-847, 1998.

[31] J. R. Stabel, "Cytokine secretion by peripheral blood mononuclear cells from cows infected with Mycobacterium paratuberculosis," American Journal of Veterinary Research, vol. 61, no. 7, pp. 754-760, 2000.

[32] P. M. Coussens, N. Verman, M. A. Coussens, M. D. Elftman, and A. M. McNulty, "Cytokine gene expression in peripheral blood mononuclear cells and tissue of cattlenfected with Mycobacterium avium subsp. paratuberculosis : evidence for an inherent proinflammatory gene expression pattern," Infection and Immunity, vol. 72, no. 3, pp. 1409-1422, 2004.

[33] E. Martin, A. T. Kamath, J. A. Triccas, and W. J. Britton, "Protection against virulent Mycobacterium avium infection following DNA vaccination with the 35-kilodalton antigen is accompanied by induction of gamma interferon-secreting CD4+ T cells," Infection and Immunity, vol. 68, no. 6, pp. 3090-3096, 2000.

[34] M. A. Chambers, A. Williams, G. Hatch et al., "Vaccination of guinea pigs with DNA encoding the mycobacterial antigen MPB83 influences pulmonary pathology but not hematogenous spread following aerogenic infection with Mycobacterium bovis," Infection and Immunity, vol. 70, no. 4, pp. 2159-2165, 2002.

[35] M. Pardini, F. Giannoni, C. Palma et al., "Immune response and protection by DNA vaccines expressing antigen $85 \mathrm{~B}$ of Mycobacterium tuberculosis," FEMS Microbiology Letters, vol. 262, no. 2, pp. 210-215, 2006. 
[36] L. A. Sechi, L. Mara, P. Cappai et al., "Immunization with DNA vaccines encoding different mycobacterial antigens elicits a Th1 type immune response in lambs and protects against Mycobacterium avium subspecies paratuberculosis infection," Vaccine, vol. 24, no. 3, pp. 229-235, 2006.

[37] P. Andersen, "TB vaccines: progress and problems," Trends in Immunology, vol. 22, no. 3, pp. 160-168, 2001.

[38] S. H. E. Kaufmann, "How can immunology contribute to the control of tuberculosis?" Nature Reviews Immunology, vol. 1, no. 1, pp. 20-30, 2001.

[39] R. A. Goldsby, T. J. Kindt, B. A. Osborne, and J. Kuby, Immunology, W.H. Freeman and Company, New York Press, New York, Ny, USA, 5th edition, 2003.

[40] S. Xiao, H. Chen, L. Fang et al., "Comparison of immune responses and protective efficacy of suicidal DNA vaccine and conventional DNA vaccine encoding glycoprotein $\mathrm{C}$ of pseudorabies virus in mice," Vaccine, vol. 22, no. 3-4, pp. 345351, 2004.

[41] S. H. Basagoudanavar, P. P. Goswami, and V. Tiwari, "Cellular immune responses to $35 \mathrm{kDa}$ recombinant antigen of mycobacterium avium paratuberculosis," Veterinary Research Communications, vol. 30, no. 4, pp. 357-367, 2006.

[42] Y. H. Chow, W. L. Huang, W. K. Chi, Y. I. D. Chu, and M. I. H. Tao, "Improvement of Hepatitis B Virus DNA Vaccines by Plasmids Coexpressing Hepatitis B Surface Antigen and Interleukm-2," Journal of Virology, vol. 71, no. 1, pp. 169-178, 1997.

[43] X. Zhu, N. Venkataprasad, H. S. Thangaraj et al., "Functions and Specificity of T Cells Following Nucleic Acid Vaccination of Mice Against Mycobacterium tuberculosis Infection," Journal of Immunology, vol. 158, no. 12, pp. 5921-5926, 1997.

[44] P. Lefèvre, O. Denis, L. De Wit et al., "Cloning of the gene encoding a 22-kilodalton cell surface antigen of Mycobacterium bovis BCG and analysis of its potential for DNA vaccination against tuberculosis," Infection and Immunity, vol. 68, no. 3, pp. 1040-1047, 2000.

[45] A. T. Kamath, T. Hanke, H. Briscoe, and W. J. Britton, "Coimmunization with DNA vaccines expressing granulocytemacrophage colony-stimulating factor and mycobacterial secreted proteins enhances T- cell immunity, but not protective efficacy against Mycobacterium tuberculosis," Immunology, vol. 96, no. 4, pp. 511-516, 1999.

[46] J. P. Y. Scheerlinck, G. Casey, P. McWaters et al., "The immune response to a DNA vaccine can be modulated by co-delivery of cytokine genes using a DNA prime-protein boost strategy," Vaccine, vol. 19, no. 28-29, pp. 4053-4060, 2001.

[47] M. Parra, N. Cadieux, T. Pickett, V. Dheenadhayalan, and M. J. Brennan, "A PE protein expressed by Mycobacterium avium is an effective T-cell immunogen," Infection and Immunity, vol. 74, no. 1, pp. 786-789, 2006.

[48] S. H. Basagoudanavar, P. P. Goswami, V. Tiwari, A. K. Pandey, and N. Singh, "Heterologous expression of a gene encoding a $35 \mathrm{kDa}$ protein of Mycobacterium avium paratuberculosis in Escherichia coli," Veterinary Research Communications, vol. 28, no. 3, pp. 209-224, 2004.

[49] S. J. Shin, H. S. Yoo, S. P. McDonough, and Y. F. Chang, "Comparative antibody response of five recombinant antigens in related to bacterial shedding levels and development of serological diagnosis based on $35 \mathrm{kDa}$ antigen for Mycobacterium avium subsp. paratuberculosis," Journal of Veterinary Science, vol. 5, no. 2, pp. 111-117, 2004.

[50] K. Kathaperumal, V. Kumanan, S. McDonough et al., "Evaluation of immune responses and protective efficacy in a goat model following immunization with a coctail of recombinant antigens and a polyprotein of Mycobacterium avium subsp. paratuberculosis," Vaccine, vol. 27, no. 1, pp. 123-135, 2009.

[51] J. L. Flynn and J. Chan, "Immunology of tuberculosis," Annual Review of Immunology, vol. 19, pp. 93-129, 2001. 

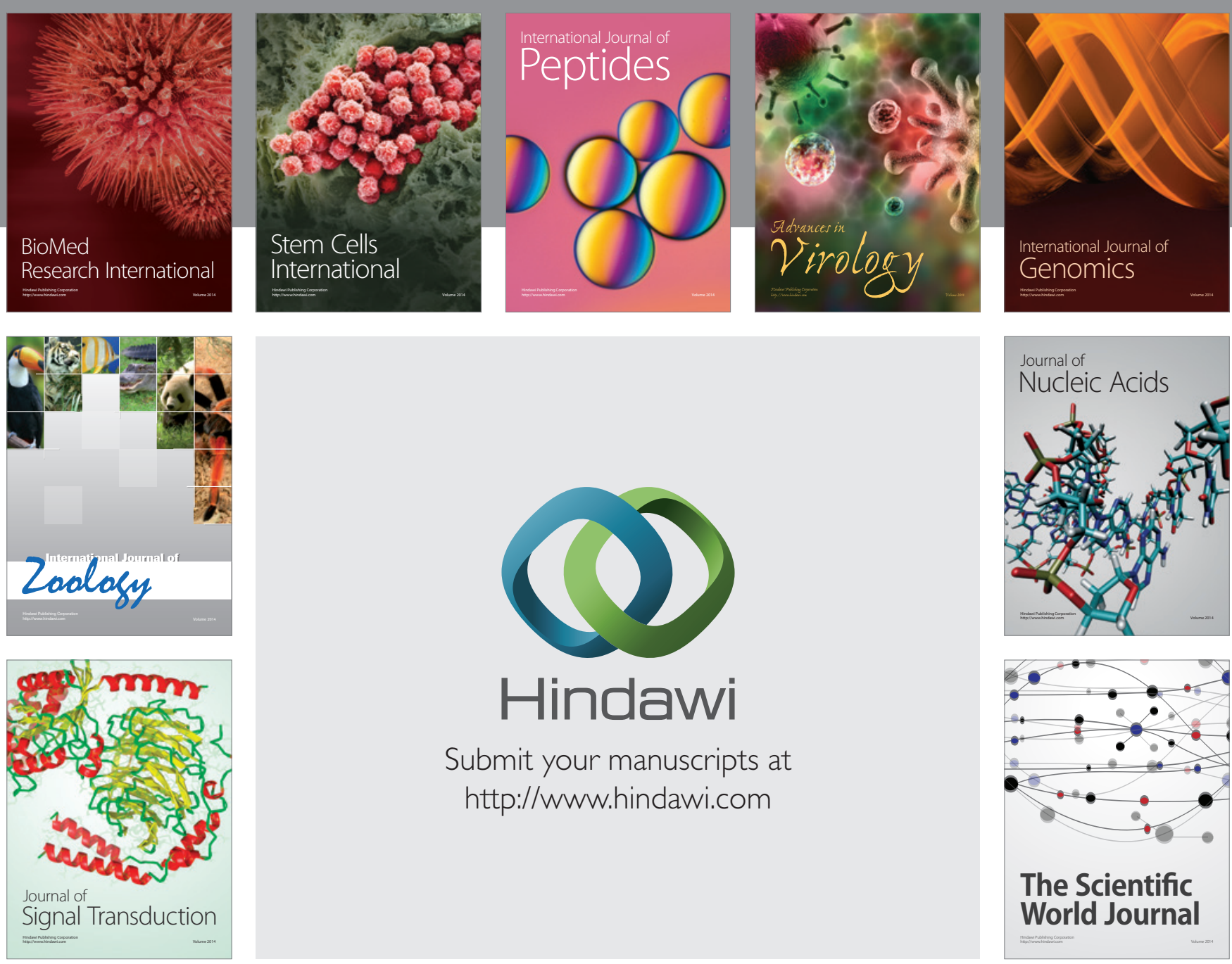

Submit your manuscripts at

http://www.hindawi.com
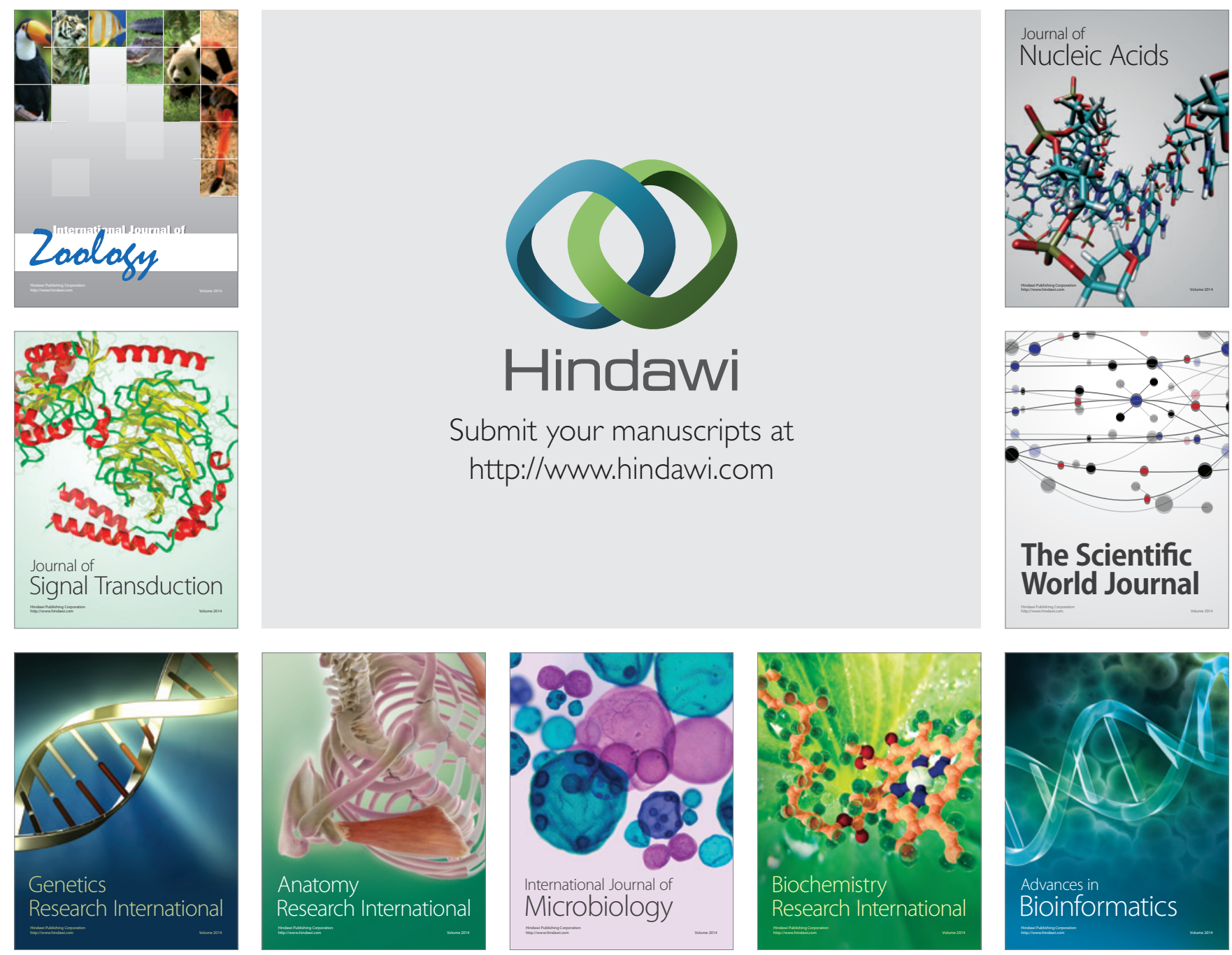

The Scientific World Journal
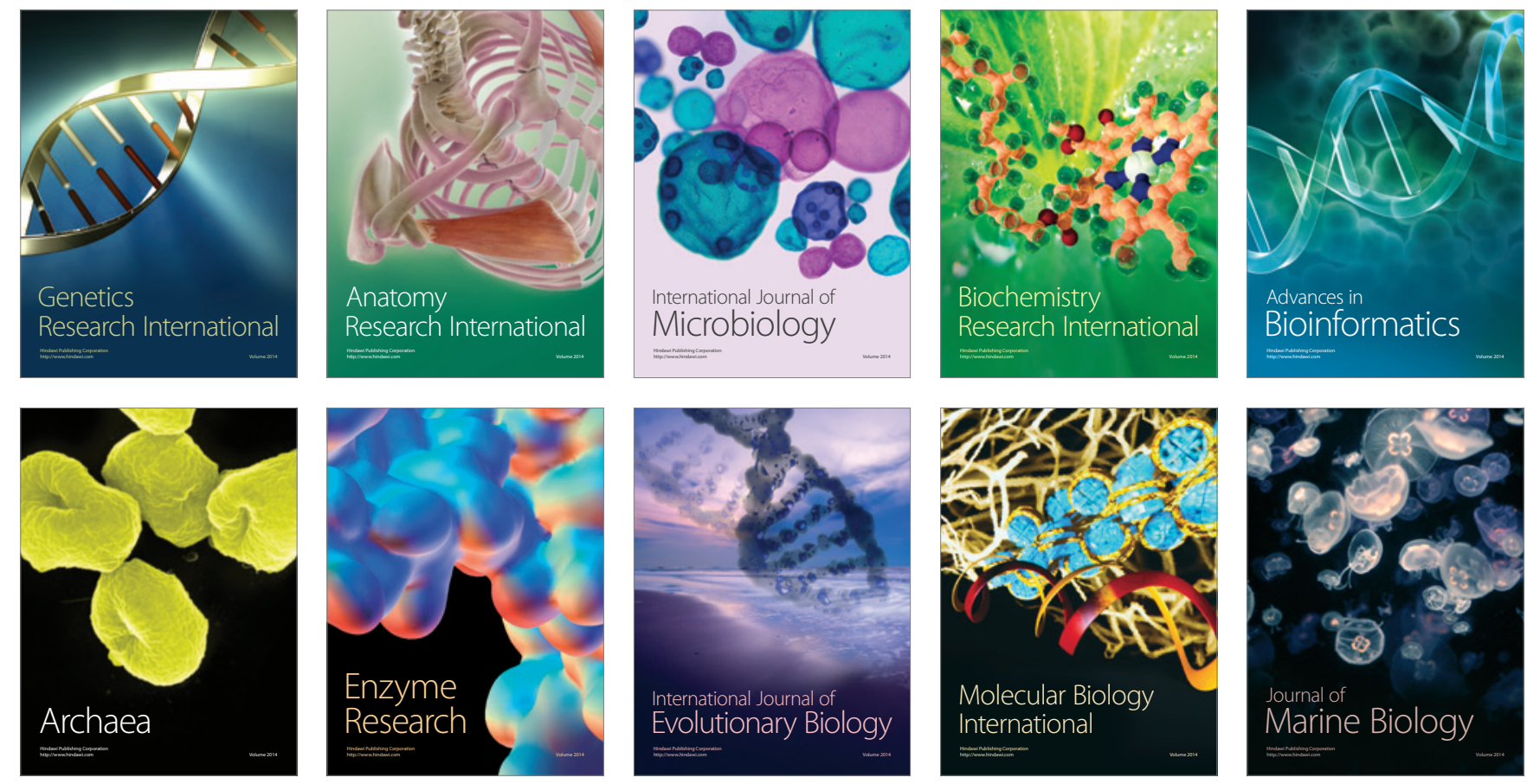